\title{
The Integrated Model for the Relationship between Banking Risks, Liquidity, Capital Adequacy, and Profitability in Commercial Banks in the Libyan West
}

Salim Mohamed Alajili ${ }^{1 *}$, Tarq A. M. Mahmud ${ }^{2}$, Abd Ussalam Mohamed Altunesi ${ }^{3}$, Khalid Mustafa Mohsmmed Bin Jumuah $^{4}$

${ }^{1}$ Lecturer (Department of Business Administration) in Al-Marqab University

${ }^{2}$ Lecturer (financial department) in Al-Marqab University

${ }^{3}$ Lecturers (Department of Business Administration) in Al-Marqab University

${ }^{4}$ Lecturer (Department of Business Administration) in Al-Marqab University

*Corresponding author: Salim Mohamed Alajili

Abstract

Original Research Article

The essential aim of this study is to evaluate the influence of capital adequacy, liquidity, banking risk on bank profitability. The relationships model was built based on liquidity and profitability theories and supported by previous studies. Random sampling is adopted, 320 questionnaires among officers of banks were distributed and 270 out of them were returned and valid for analysis. The findings revealed that liquidity don't have any direct effect on profitability, but it has indirect influence on profitability through banking risk since the mediation was complete. On the contrary, in relation to financial risk, it has a direct impact on profitability and there is no significant indication regarding its indirect impact. Moreover, the results referred that both market risk and liquidity risk had positive significant effects on return on assets, whiles other factors did not support any influence. The study recommends the use of mediator and non-quantitative factors such as the reputation of the bank, customer and employee satisfaction, confidence in the direction of the bank in order to improve the profitability of banks.

Keywords: liquidity, banking risk, influence, banks.

Copyright @ 2020: This is an open-access article distributed under the terms of the Creative Commons Attribution license which permits unrestricted use, distribution, and reproduction in any medium for non-commercial use (NonCommercial, or CC-BY-NC) provided the original author and source are credited.

\section{INTRODUCTION}

This study examines the effect of bank capital, bank liquidity and credit risk on the profitability of commercial banks in the Libyan west from perspective of officials and executives in those banks. The available literature on the topic includes theoretical and experimental discrepancies, consequently misleading interested in this filed. The findings of past analyses indicate that the effect of credit risk on the profitability of banks is not clear; it may be positive or negative. Theoretically, a bank that takes higher credit risk, it normally earns a higher profit. In contrast, the profitability of bank may drop when it management fails to collect the loans. Further, the previous findings of relationship between bank liquidity and profitability referred to be inverse. Meaning, banks which keep a greater amount of liquid assets they lose the profits in term of opportunity costs [1]. In same line, capital theory suggests that bank capital is one of the key determinants of profitability increase and decrease, since the high level of bank's capital enhances trust of the public about the soundness of the bank. Therefore, this study aims to provide new insights based on empirical findings.

The significance of the under-consideration subject is clearly manifested by reviewing the opinions of managers in the banks to arrive at a model that logically explains the chronological arrangement of the relationships under study. Moreover, and through a critical review of previous studies that dealt with the relationships among Bank's Credit Risk, Liquidity, and Capital Adequacy towards its Profitability such as, [14]. Amaliah and Hassan (2019), Bassey, Tobi, Bassey, and Ekwere (2016), and Abbas, Iqbal, and Aziz's (2019) works that included the direct relationships ignoring the indirect impacts. Thus, this study will examine direct and indirect models. The best model is recommended that explains the profitability better than others.

However, in last global financial crisis (20072008), The Basel Committee on Banking Supervision (BCBS) formulated new regulations. For example, the 
BCBS regulators recommend that financial institutions be required to maintain a higher proportion of capital and liquid assets. Accordingly, financial institutions have to bear a heavy cost in terms of lower profitability and slower economic activities.

This study highlights the effect of the liquidity, banking risk, and capital Adequacy on the profitability from perspective of managers and officials in commercial banks in west Libya. In this study, the questionnaire is established to measure the variables of the study. Moreover, the authors try to extend the set of relationships to include the influence of the four dimensions of banking risk on the two dimensions of profitability, thus this study could be the first in this aria.

The findings of this study provide constructive feedback to interestedabout the effect of banking risk, liquidity and capital on profitability for further decision-making and regulations.

\section{The Problem Statement}

Banks are seeking to maximize their expected profits on investments, and at the same time they should be ready to meet the obligations of their clients and depositors who want to withdraw their savings. Today, Libya is undergoing fragile economic, security, political and social conditions. These issues affected the performance of the Libyan institutions in general and the banking sector in particular. Therefore, the problem arises when the Bank is not able to meet these demands, especially those unexpected ones, which may embarrass the bank with its clients and may lose their trust over the time, in light of the intensive competition in the banking sector resulting from the increasing number of local banks, as well as intensive competition from the foreign banks that work in the local banking market.

\section{RESEARCH OBJECTIVES}

This paper aims at investigating the influence of the banking risk, liquidity, and capital adequacy on profitability in the Libyan commercial banks, considering the mediating role of the study variables.

\section{LITERATURE REVIEW}

This research presents some of the previous studies about the effect of banking risk, liquidity, and capital adequacy on banks' profitability, and an analytical view in order to identify the similarities and differences between them and what the current study offers in this regard.

\section{Profitability}

Profitability is the ability to make profit from the overall business activities [3 Profitability defined as "the ability of a given investment to earn a return from its use", 5]. Profitability consists of profit and ability. Profit refers to an absolute amount of income generated by the company within a period of time, while ability indicates the power of a business entity to earn profits [5].

Profitability can be measured using the profitability ratio. Return on assets (ROA) and Return on Equity (ROE) are the most important earnings ratios used in assessing the bank profitability. The ROA ratio measures the efficiency of a firm at generating profits from each unit of shareholder equity, also known as net assets or assets minus liabilities. While, ratio measures the efficiency of a firm at generating profits from each unit of shareholder equity, also known as net assets or assets minus liabilities [6].

\section{Capital adequacy}

Capital adequacy is "the minimum reserves of capital that the bank must have available [3, 7]" stated that capital adequacy promote he strength of the bank and improve the solvency of the bank because it works to absorb unexpected expenses. Practically, adequate capital prevents the bank failure by absorbing the losses and provides a protection versus the insolvency and liquidation arising from the risks. Therefore, capital adequacy ensures that the bank is still on operation and be able to sustain in the market and provides a confidence that the bank is safe and is able to pay them on demand [3].

\section{Liquidity}

Banks can only work under the state of adequate liquidity. Banks seek to keep balanced cash in the vault and do not allow excess liquidity. Accordingly, the banks have to efficiently manage their liquidity in order to maximized revenues while holding risks of insolvency at a desired level. Liquidity is the ability to pay on demand. It is an ability of the bank to increase the funds and meet its short-term obligation without incurring unreasonable loss [4]. Therefore, efficient and effective liquidity management is crucial if the survival and prosperity of organizations firms is to be assured.

There are a number of liquidity management theories, as follows: First of all, The Liquid Asset Theory which suggests that banks should maintain large pool short-term asset in order to meet their short term obligation as they mature. The second is Commercial Loan Theory in which states that lending should be on short-term because most deposits are also in short-term [4].

Third is Liability Management Theory. This theory states that there is no need to follow old liquidity norms like maintaining liquid assets, liquid investments etc, but considering both sides of a bank's balance sheet as sources of liquidity [8]. Lastly, Anticipated Loan Theory in which concentrates on the earning strength and the credit worthiness of the borrower as the main source of bank liquidity. The anticipated income theory encouraged bankers to treat long-term loans as potential sources of liquidity. In this regard, these loans are 
typically paid off by the borrower in a series of installments [8].

\section{Banking Risk}

Major risks for banks include credit, operational, market, and liquidity risk [9]. Credit risk is the biggest risk for banks. Although, the credit function of banks enhances the ability of investors to exploit desired profitable ventures, it exposes the banks to credit risk [10].

Credit risk occurs when borrowers or counterparties fail to meet contractual obligations in accordance with agreed terms [11]. Credit risk takes several shapes such as loans, acceptances, interbank transactions, trade financing, foreign exchange transactions, financial futures, swaps, bonds, and equities [12]. The Basel committee on Banking Supervision reported that the lenient on credit standard for the borrowers is the main causes that lead to credit risk [3]. Moreover, [10] suggested that the poor management, inappropriate credit policies, fluctuation of the interest rate, low capital and liquidity level, inappropriate credit assessment, poor lending practices, poor loan underwriting, government interference, and inadequate supervision by the central bank are major factors that leads to credit risk.

Credit risk is measured by several indicators, which are: nonperforming loan ratio, nonperforming loan to loan advance ratio, total loan and advance to total deposit ratio, and loan loss provision to classified loan ratio [3]. The most commonly used in literature is nonperforming loan to total loan ratio, where nonperforming loans is a major threat in banking sector and will directly affect the performance of the bank due to the bad loans.

There are several types of market risks. They are equity risk, Forex risks, and commodity risks. Equity risk occurs when the banks are holding a large amount of equity. Forex risks happen when the banks hold foreign exchange. A commodity risk occurs when the banks lend against commodities like gold, silver and real estate. For facing these risks, banks have to use hedging contracts. Hence, the banks use financial derivatives which are freely available for sale in any financial market. Using contracts like forwards, options and swaps, banks are able to almost eliminate market risks from their balance sheet.

Lastly, liquidity risk which is the inability of the bank to provide duo to the banks were not fully taking into account the importance of liquidity management [3]. According to this definition, liquidity risk has two essential dimensions which are liquidating the assets as and when required; and at a fair market value [13]. In literature, there are several source of liquidity risk [14] revealed that the extensive commitment based, and long-term lending may create serious liquidity issues. In addition, [13] reported that credit risk also leads to the vulnerability of liquidity, and therefore, nonperformance lone reduces the liquidity of the banks.

\section{HYPOTHESES OF THE STUDY \\ The Relationship between Bank Capital and Profitability \\ Olalekan A, Adeyinka S [15] revealed a non-} significant relationship between capital adequacy and profitability of bank for the primary data analysis. In the relation of capital adequacy as a determinant of profitability of banks [16] revealed that a high capital adequacy ratio should signify a bank that is operating over-cautiously and ignoring potentially profitable trading opportunities. Accordingly, a negative relationship is between equity to asset ratio and bank profitability [15]. Suggested that the direction of the relationship between bank capital and bank profitability cannot be unanimously predicted in advance. This leads to the first hypothesis:

Bank Capital does not impact on profitability of Libyan commercial banks.

\section{The Relationship between Bank Liquidity and Profitability in Banking}

The findings of studies that examined the relationship between liquidity and profitability led to conflicting results [17] argued that banks which have well-various lending portfolio gathered higher profits along with higher liquidity [18]. Detected that liquidity has a positive influence on bank profitability. This is duo to the higher liquid assets reduce the illiquidity and financing cost of banks [19]. On the other hand [20], appeared that liquidity (total loans to total deposit ratio) has a positive influence on profitability in case of net interest margin.

Unlike, [21] revealed that the relationship liquidity and profitability was negative. Olalekan, A., \& Adeyinka , S. [16] supported the negative relationship. In this context, [22] opines that the banks which create higher liquidity gain lower profits. More important, [1] reported that the impact of liquidity on the profitability of the USA large commercial banks is negative and positive on Asian developed economies commercial banks in the post crisis era. Moreover, the results of [23] study revealed that there is a significant impact of only liquid ratio on return on assets while insignificant on return on equity and return on investment. This leads to the second hypothesis:

Bank Liquidity affects profitability of Libyan commercial banks.

\section{The Relationship between Banking Risk and Profitability}

There is some degree of correlation between risk and profit. The relationship between risk and profit varies depending on economists or stock brokers [12]. 
Results of [24] study pointed out a negative relationship between less prudent lending (which may be interpreted as a positive effect of more prudent lending) and net interest margin [25]. Found a negative relationship between equity levels and credit risk. In another study [26], revealed that the liquidity risk has positive while credit risk, insolvency risk and competition hurt negatively the profitability of Pakistani banks.

In addition, Kolapo et al. also find a negative relationship between credit risk and the profitability on 5 Nigerian commercial banks over 2000-2010 [27].

Ruziqa A [28] investigates the joint effect of credit risk and liquidity risk on the profitability of large banks of Indonesia and finds negative effect of credit risk and positive effect of liquidity risk on the profitability. This leads to the third hypothesis:

Banking Risk impacts on profitability of Libyan commercial banks

\section{METHODOLOGY}

Most of past studies used financial ratios for determining the effect of credit risk on profitability. However, the extent of those studies does not reach at any conclusive evidence regarding the effect of credit risk on profitability of the banks [3]. Therefore, this study tries to measure the relationships among the variables from perspective of officials and executives of Libyan banks.

A questionnaire was used to data collection. The questionnaire was designed to measure study variables by the authors. It consists of 42 items, since 22 of them measure banking risk which both credit risk and operational risk involve on 5 items, 5 items for market risk, while liquidity risk includes 7 items. In addition, liquidity involves on 7 items, and lastly, profitability was measured by 13 items.

The questionnaire was randomly distributed to 320 respondents of bank's officers. The participants belong to the four largest commercial banks in western Libya. Those banks are Sahara Bank, Al-Wahda Bank, Al- Gumhouria Bank, and National Commercial Bank.
40 questionnaires were excluded from the analysis. SPSS version 22 was used to describe the study population, conducting exploratory factor analysis and reliability, while Amos used the 22 version to test the hypotheses.

\section{Analytic strategy}

Data for this study were simple, multiple, and hierarchical in nature. Therefore, multiple and hierarchical linear modelling were used to account for the nested nature of our data [29]. To find the best model of the relationships among study's variables, two scenarios were employed. First scenario is to examine direct impact by the multiple regressions. The second is to test the indirect relationships that occur in existence a mediator variable.

\section{Exploratory Factor Analysis}

Exploratory Factor Analysis (EFA) was used to reduce the data having redundancy with each other by way of Principal Component Analysis (PCA). The EFA was performed several times for all the indicators separately. The last analysis was done for all items combined. The results of analysis revealed that five items of banking risk, four items of liquidity, two capital adequacy, and five items of profitability were removed due to lower value of communalities for some items than .6 or because some items are loaded for two factors. Moreover, the value of Kaiser Meyer Olkin (KMO) for all constraints exceeds the recommended value of KMO that is 0.6 [30] as it is shown in Table 1. In the other words, the adequacy of the sample has been achieved.

Table 1 showed that banking risk was loaded by four factors which are Credit Risk (CR) (CR1 to CR4), Operational Risk (OP) (OP1 to OP4), Market Risk (MR) (MR1 to MR4), and Liquidity Risk (LR) (LR1, LR3, LR4). On the other hand, profitability was loaded by two factors which are Return on Assess (ROA) including items (ROA3, ROA4, ROA6, ROA7), and Return on Equity (ROE) involving items (ROE1, ROE3, ROE4, ROE5). Whiles, liquidity by items (L1, L2, L3) and capital adequacy by items (CA1, CA2, CA4) were loaded by one factor for each. 
Table-1: Rotated Component Matrix of Exploratory Factor Analysis

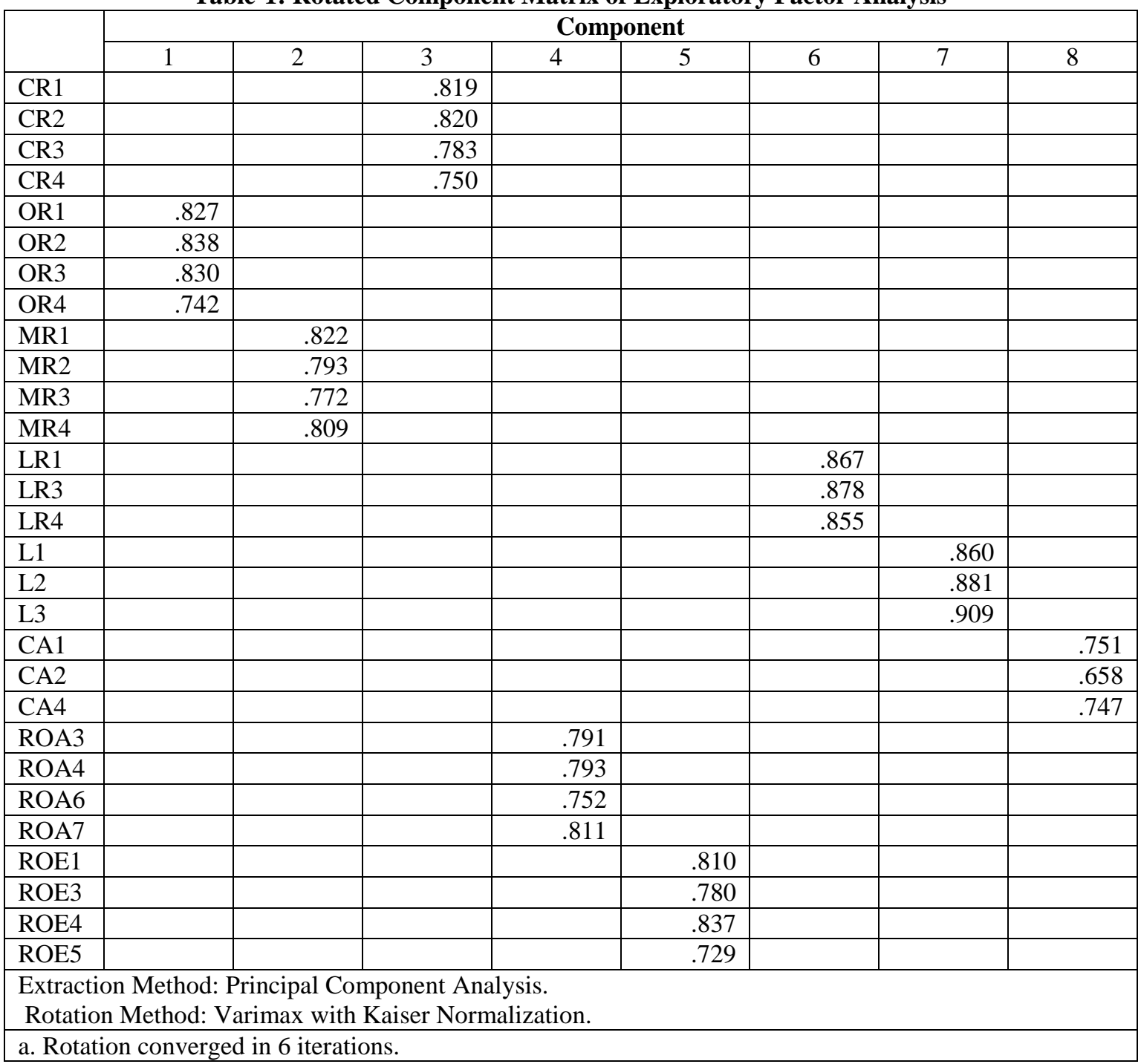

\section{Reliability of the Scales}

To verify the consistency of the data and its internal consistency, as previously mentioned, the Cronbanch's Alpha test was conducted. Table 2 shows that alpha value for each variable is more than 0.70 except for capital adequacy (Cronbach's $\alpha=.582$ ), indicating acceptable values to determine internal consistency since alpha values for banking risk, liquidity, and profitability were $.904, .886$, and .856 respectively. Table 2 revealed also that Cronbach's coefficients alpha of items related to banking risk, liquidity, and profitability exceeded .70 . Thus the scales were satisfactorily reliable for subsequent analysis. With regard to capital adequacy, the table displayed that the coefficients of alpha were unsatisfied since they ranged from .437 to .551 . In this issue, the Researchers decided not to delete the variable but testing it for validity. 
Table-2: Reliability Test on the Scales

\begin{tabular}{|c|c|c|}
\hline Item & Cronbach's $\alpha$ & Cronbach's $\alpha$ of Banking Risk \\
\hline CR1 & .896 & \multirow{15}{*}{.904} \\
\hline CR2 & .896 & \\
\hline CR3 & .896 & \\
\hline CR4 & .895 & \\
\hline OR1 & .898 & \\
\hline OR2 & .897 & \\
\hline OR3 & .898 & \\
\hline OR4 & .897 & \\
\hline MR1 & .896 & \\
\hline MR2 & .898 & \\
\hline MR3 & .900 & \\
\hline MR4 & .897 & \\
\hline LR1 & .899 & \\
\hline LR3 & .899 & \\
\hline LR4 & .898 & \\
\hline Item & Cronbach's $\alpha$ & Cronbach's $\alpha$ of Liquidity \\
\hline L1 & .870 & \multirow[t]{3}{*}{.886} \\
\hline $\mathrm{L} 2$ & .823 & \\
\hline L3 & .818 & \\
\hline Item & Cronbach's $\alpha$ & Cronbach's $\alpha$ of Capital Adequacy \\
\hline CA1 & .444 & \multirow[t]{3}{*}{.582} \\
\hline CA2 & .551 & \\
\hline CA4 & .437 & \\
\hline Item & Cronbach's $\alpha$ & Cronbach's $\alpha$ of Profitability \\
\hline ROA3 & .836 & \multirow[t]{8}{*}{.856} \\
\hline ROA4 & .840 & \\
\hline ROA6 & .836 & \\
\hline ROA7 & .838 & \\
\hline ROE1 & .833 & \\
\hline ROE3 & .835 & \\
\hline ROE4 & .843 & \\
\hline ROE5 & .848 & \\
\hline
\end{tabular}

\section{Validity of the Scales}

Although the reliability is necessary but it is not sufficient condition for validity [31]. Validity refers to the degree to which a study accurately reflects or assesses the specific concept that the researcher is attempting to measure [32].

For this study, construct validity, discriminant validity, and discriminant validity are recommended. Construct validity is achieved when the fitness indexes for a construct achieved the required. The level of acceptance should be .90 or higher. The convergent validity refers to the extent of correlation between the dimension and the measurement items it represents. It could be verified by computing the Average Variance Extracted (AVE) for every construct that should be 0.5 or higher. While discriminant validity refers to the demonstrations that a measure of a construct is unrelated to indicators of theoretically irrelevant constructs in the same domain [33].
Confirmatory Factor Analysis (CFA) was performed in order to estimate the general fit of the model through several different indicators. The most important of these indicators are the approximate Root Square Average Root Indicator (RMSEA $<.08$ suitable), Goodness of Fit Index (GFI), Tucker-Lewis Index, and Comparative Fit Index (CFI). All these indices should have level of acceptance greater than .90 [33].

The results of CFA for measurement model are shown in Figure 1. In the first, the fitness indices were not achieved, and therefore, CFA was done another time. The results of second analysis indicated that all fitness indices in measurement model achieved the levels of fit acceptance after filtering the model. In filtered model, capital adequacy construct was excluded as well as some items representing in CR3 and OR3. Therefore, fitness indices achieved the levels of acceptance, since chi-square $\left(\chi^{2}\right)$ was 290.617 , DF was 242, GFI reached .92, CFI reached .98, RMSEA reached .027 , and p- value was .018 for the model. 


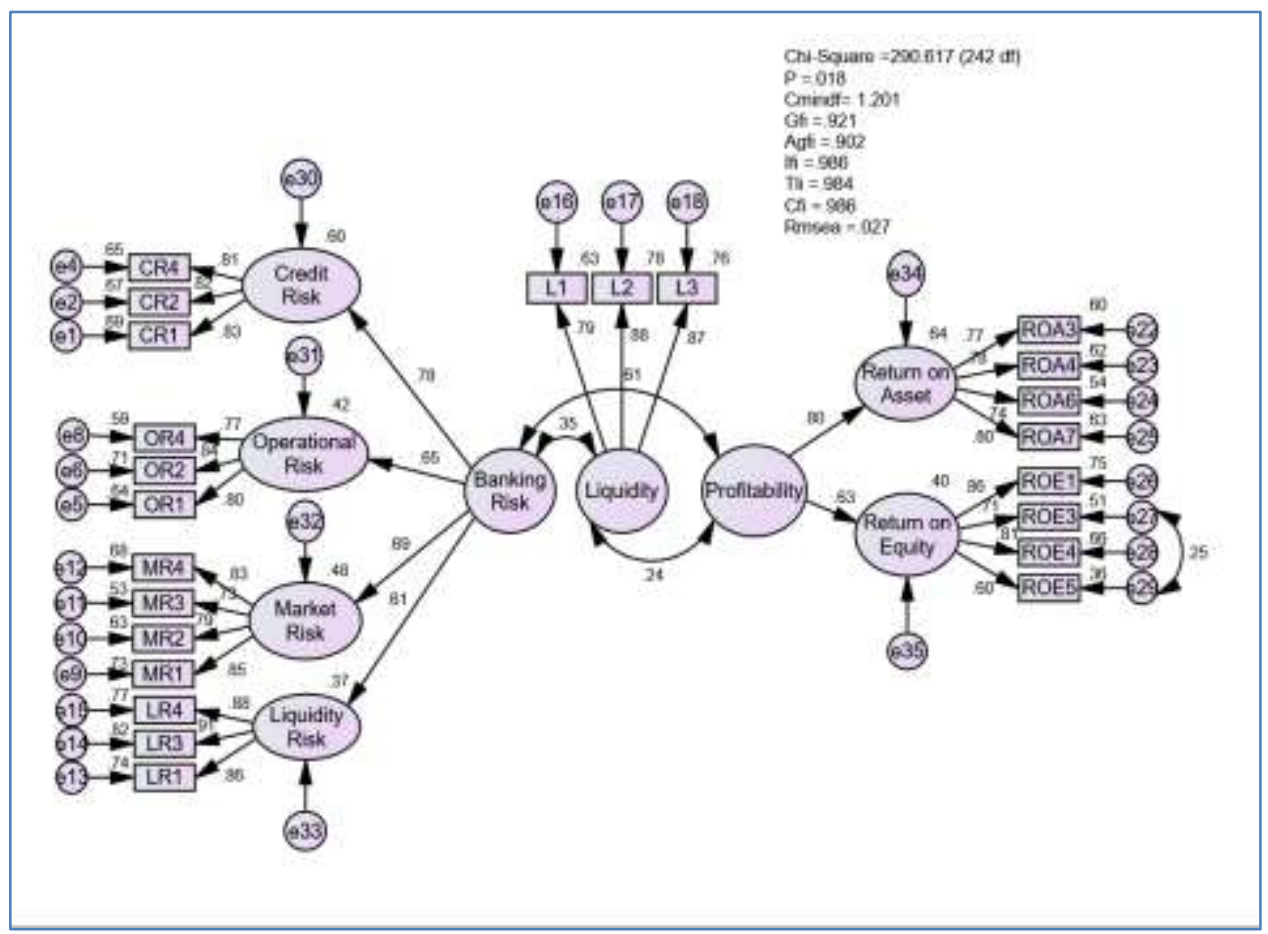

Fig-1: Filtered Measurement Model

For convergent validity, Table 3 summarises the convergent validity, since it displays factors loading, Composite Reliability (CR) is calculated from (http://www.thestatisticalmind.com/composite-

reliability), and Average Variance Extracted (AVE) is obtained by the sum of the standard errors of the items in the factor divided by the number of those items. The table provides evidence of convergent validity since the AVE values for all constructs exceeded .50 .

Table-3: Evidence of Convergent Validity for Constructs of the Study

\begin{tabular}{|c|c|c|c|c|c|}
\hline Construct & Factor & Item & Factor Loading & CR & AVE \\
\hline \multirow[t]{13}{*}{ Banking Risk } & \multirow[t]{3}{*}{ Credit Risk } & CR1 & .83 & & \multirow[t]{3}{*}{.72} \\
\hline & & CR2 & .82 & & \\
\hline & & CR4 & .81 & & \\
\hline & \multirow[t]{3}{*}{ Operational Risk } & OR1 & .80 & & \multirow[t]{3}{*}{.65} \\
\hline & & OR2 & .84 & & \\
\hline & & OR4 & .77 & & \\
\hline & \multirow[t]{4}{*}{ Market Risk } & MR1 & .85 & & \multirow[t]{4}{*}{.64} \\
\hline & & MR2 & .79 & & \\
\hline & & MR3 & .73 & & \\
\hline & & MR4 & .83 & & \\
\hline & \multirow[t]{3}{*}{ Liquidity Risk } & LR1 & .86 & & \multirow[t]{3}{*}{.78} \\
\hline & & LR3 & .91 & & \\
\hline & & LR4 & .88 & & \\
\hline \multirow[t]{3}{*}{ Liquidity } & \multirow[t]{3}{*}{-} & L1 & .79 & & \multirow[t]{3}{*}{.72} \\
\hline & & $\mathrm{L} 2$ & .88 & & \\
\hline & & L3 & .87 & & \\
\hline \multirow[t]{8}{*}{ Profitability } & \multirow[t]{4}{*}{ Return on assess } & ROA3 & .77 & & \multirow[t]{4}{*}{.60} \\
\hline & & ROA4 & .78 & & \\
\hline & & ROA6 & .74 & & \\
\hline & & ROA7 & .80 & & \\
\hline & Return on Equity & ROE1 & .86 & & \multirow[t]{4}{*}{.57} \\
\hline & & ROE3 & .71 & & \\
\hline & & ROE4 & .81 & & \\
\hline & & ROE5 & .60 & & \\
\hline
\end{tabular}


For discriminant validity, two conditions should be met which are: a) Foreter and Larker's criterion which refers to the Average Variance Extracted (AVE) is greater than Common Variance (CV); b) Composite Reliability (CR) greater than Average Variance Extracted (AVE). The discriminant validity is explained in Table 4.
In Table 4, the diagonal values (in bold) is the square root of AVE of the construct while other values are the correlation among constructs. It is clear that AVE greater than common variance and therefore, discriminant validity is achieved for all constructs.

Table-4: Discriminant Validity using Foreter and Larker Criteria

\begin{tabular}{|l|c|c|c|}
\hline \multicolumn{1}{|c|}{ Construct } & Banking Risk & Liquidity & Profitability \\
\hline Banking Risk & $\mathbf{. 8 2}$ & & \\
\hline Liquidity & .35 & $\mathbf{8 2}$ & \\
\hline Profitability & .61 & .24 & $\mathbf{. 7 6}$ \\
\hline
\end{tabular}

Normality, Linearity, and Multicollinearity Assumptions

Normality test, Linearity test, and Multicollinearity were performed to meet the assumptions of hierarchical regression. For normality, skewness and kurtosis were used to judge the distribution of dataset. As [30] work, values of skewness and kurtosis should fell in range \pm 1 and \pm 3 respectively. Table 4 revealed results of normality test. The Table revealed that all values of skewness and kurtosis fill fell within the range recommended.

Table-5: Summary of Assessment of normality

\begin{tabular}{|l|r|r|r|r|r|r|}
\hline Variable & min & max & skew & c.r. & kurtosis & c.r. \\
\hline ROE5 & 1.000 & 5.000 & -.437 & -2.930 & -.368 & -1.233 \\
\hline ROE4 & 1.000 & 5.000 & -.431 & -2.894 & -.006 & -.019 \\
\hline ROE3 & 1.000 & 5.000 & -.269 & -1.803 & -.292 & -.981 \\
\hline ROE1 & 1.000 & 5.000 & -.252 & -1.693 & -.096 & -.321 \\
\hline ROA7 & 1.000 & 5.000 & -.085 & -.573 & -.569 & -1.909 \\
\hline ROA6 & 1.000 & 5.000 & -.083 & -.559 & -.366 & -1.227 \\
\hline ROA4 & 1.000 & 5.000 & .002 & .011 & -.357 & -1.197 \\
\hline ROA3 & 1.000 & 5.000 & .132 & .886 & -.689 & -2.309 \\
\hline L3 & 1.000 & 5.000 & -.197 & -1.320 & .029 & .098 \\
\hline L2 & 1.000 & 5.000 & -.207 & -1.386 & -.113 & -.380 \\
\hline L1 & 1.000 & 5.000 & .130 & .872 & -.309 & -1.037 \\
\hline LR4 & 1.000 & 5.000 & -.521 & -3.494 & -.072 & -.242 \\
\hline LR3 & 1.000 & 5.000 & -.543 & -3.645 & -.133 & -.447 \\
\hline LR1 & 1.000 & 5.000 & -.495 & -3.320 & -.107 & -.360 \\
\hline MR4 & 1.000 & 5.000 & -.348 & -2.334 & -.045 & -.151 \\
\hline MR3 & 1.000 & 5.000 & -.190 & -1.274 & -.219 & -.734 \\
\hline MR2 & 1.000 & 5.000 & -.133 & -.889 & -.295 & -.990 \\
\hline MR1 & 1.000 & 5.000 & -.202 & -1.354 & -.294 & -.986 \\
\hline OR4 & 1.000 & 5.000 & -.325 & -2.183 & -.486 & -1.629 \\
\hline OR2 & 1.000 & 5.000 & -.249 & -1.671 & -.134 & -.449 \\
\hline OR1 & 1.000 & 5.000 & -.326 & -2.189 & -.297 & -.996 \\
\hline CR4 & 1.000 & 5.000 & -.261 & -1.748 & -.121 & -.404 \\
\hline CR2 & 1.000 & 5.000 & -.331 & -2.223 & -.025 & -.083 \\
\hline CR1 & 1.000 & 5.000 & -.267 & -1.792 & -.217 & -.728 \\
\hline Multivariate & & & & & 37.506 & 8.723 \\
\hline
\end{tabular}

For the linearity, by examining the scatter plot residuals and predictors using SPSS 20, the results indicate a straight-line association between independent variables (banking risk and liquidity) and dependent variable (profitability), and in turn did not show any support for non-linearity. Consequently, there was no evidence to challenge the linearity assumption as shown in Figure 2. 


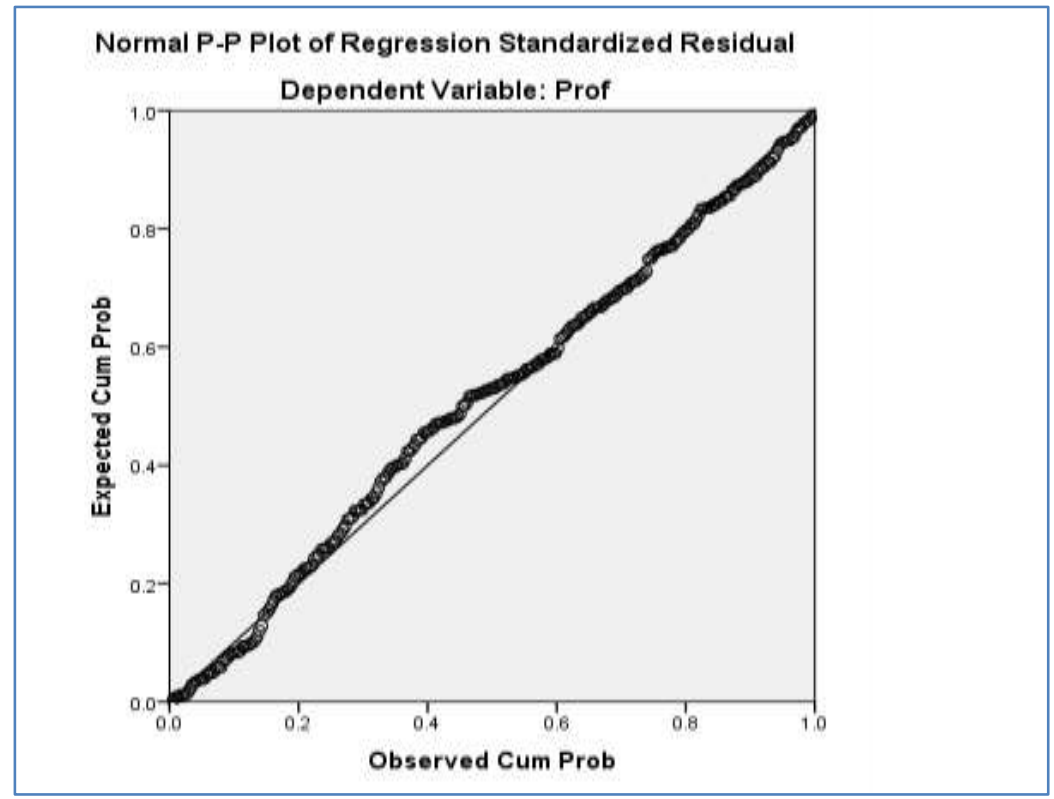

Fig-2: Linearity Assumption

Moreover, The multicollinearity test was used to investigate the correlation between independents variables the coefficients of which should not exceed 5.00 and tolerance levels should be in excess of .20 [34].
Table 6 summaries results of the test and reveals that all values of Variance Inflation Factor (VIF) are less than 5.00, which means there is no multicollinearity between all the independents variables of the study.

Table-6: Variance Inflation Factor (VIF)

\begin{tabular}{|l|c|c|}
\hline \multirow{2}{*}{ Independents Variables } & \multicolumn{2}{|c|}{ Collinearity Statistics } \\
\cline { 2 - 3 } & Tolerance $>.2$ & VIF < 5 \\
\hline Banking risk & .922 & 1.085 \\
\hline Liquidity & .922 & 1.085 \\
\hline
\end{tabular}

\section{Testing Hypotheses}

After deleting capital adequacy variable, three hypotheses should be examined in this study. Therefore, the current study is mainly seeking to investigate the relationship among banking risk, liquidity, and profitability in commercial banks in Libya. Consequently, in order to test the hypotheses developed for this study, multiple and hierarchical regression techniques were used.

On the other hand, the level of significance ( $\alpha$ level) was chosen to be 0.05 and the probability value (p-value) obtained from the statistical hypotheses test is considered to be the decision rule for rejecting the null hypotheses. If the p-value is less than or equal 0.05 , the null hypothesis will be rejected and the alternative hypothesis will be supported and vice versa.
However, to test the direct effects of liquidity and banking risk on the profitability, multiple regression liner was used. The findings of the test are shown in Table 7.

The table below shows that $F$ value was 27.45 and further revealed that the data is fitness to analysis since $\mathrm{p}$ - value lower than .05 . On the other hand, the second hypothesis was unaccepted, where $t$ value was 1.27 and p- value was significant (lower than .05). Table 7 also shows that third hypothesis was acceptable where, $\mathrm{t}$ value was 6.65 and $\mathrm{p}$ - value was significant (.000). Meaning, banking risk has a direct impact on profitability.

Table -7: Impact of liquidity and banking Risk on Profitability

\begin{tabular}{|l|l|l|l|l|l|l|l|}
\hline \multirow{3}{*}{ Model 1 } & Adjusted R Square & F & Sig. & Model 1 & Beta & t & Sig. \\
\cline { 2 - 8 } & \multirow{2}{*}{.164} & 27.45 & .000 & 'Lq & .073 & 1.27 & .207 \\
\cline { 5 - 8 } & & & & B.R & .386 & 6.65 & .000 \\
\hline
\end{tabular}

Fir testing the independent dimensions of variables which are liquidity, credit risk, operational risk, market risk, and liquidity risk on return on assets and return on Equity as represented of dependent variable, structure equation modelling was used. Figure 3 explains these relationships. 
The figure appears that all fitness indices were achieved since $\chi^{2}$ was 314.609 , DF was 231 , GFI reached .915 , CFI reached .976, RMSEA reached .037, and p- value was .000 for the model. The text output explaining the results in Figure 3 are presented in Table 8 . The table revealed

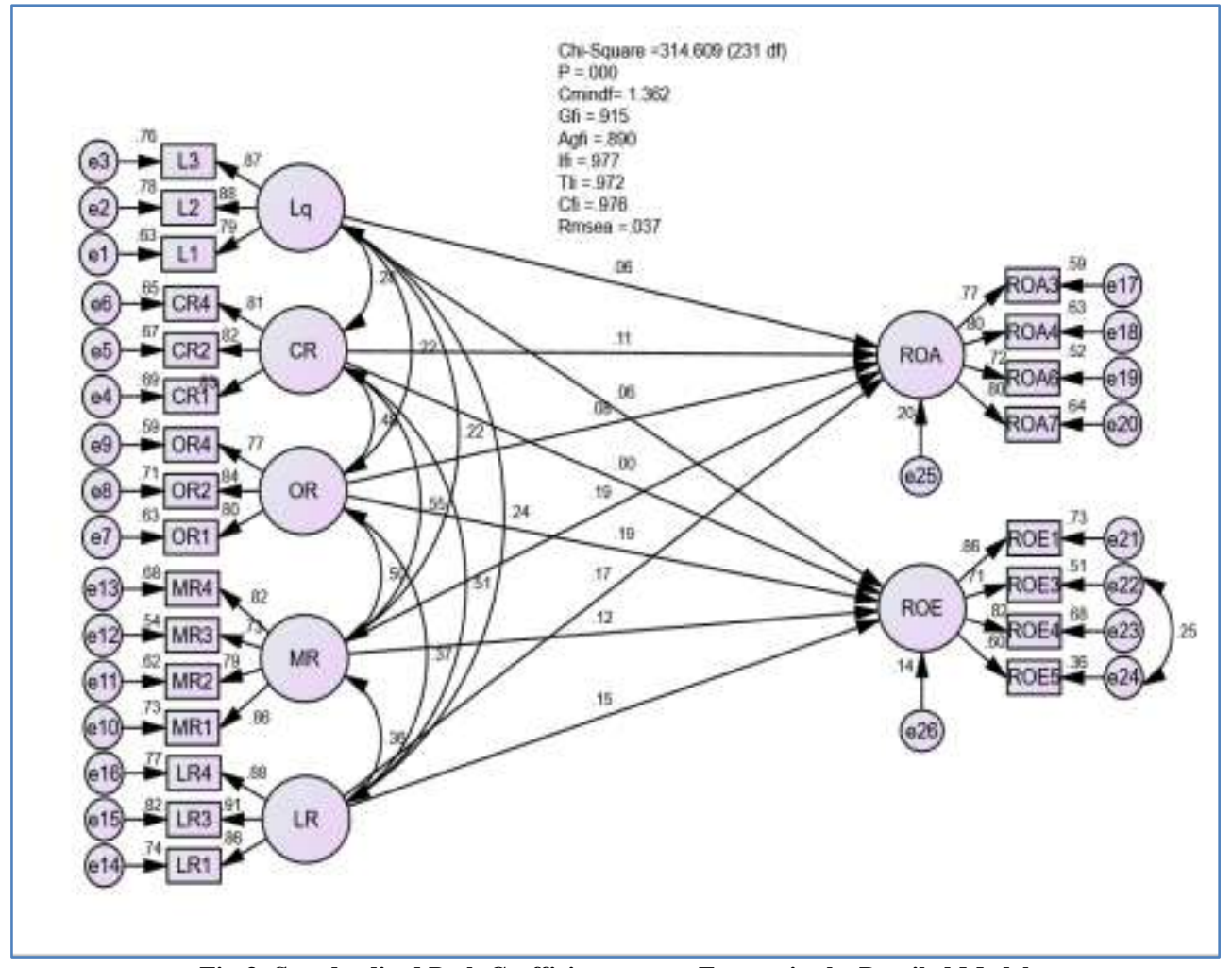

Fig-3: Standardised Path Coefficient among Factors in the Detailed Model

From Table 8, just three of independent dimensions are related to return on assets and return on Equity. It is clear that values of Critical Ratio (C.R.) for market risk, liquidity risk, and organizational risk were greater than 1.96 and p- value for each lower than .05 .
Meaning, market risk and liquidity risk have significant related to return on assets, while, operational risk has a significant effect on return on equity.

Table-8: Summary of Correlations among Dimensions of Variables

\begin{tabular}{|c|c|c|c|c|c|}
\hline path & Estimate & C.R & $\mathbf{P}$ & Status & Result \\
\hline $\mathrm{Lq} \quad-\mathrm{ROA}$ & .064 & .945 & .345 & Unsig. & Unachieved \\
\hline $\mathrm{CR}-\mathrm{ROA}$ & .110 & 1.155 & .248 & Unsig. & Unachieved \\
\hline $\mathrm{OR} \ldots \mathrm{ROA}$ & .076 & .901 & .367 & Unsig. & Unachieved \\
\hline $\mathrm{MR} \ldots \mathrm{ROA}$ & .193 & 2.205 & .027 & Sig. & Achieved \\
\hline LR $\ldots$ ROA & .169 & 2.137 & .033 & Sig. & Achieved \\
\hline $\mathrm{Lq}-\mathrm{ROE}$ & .057 & .808 & .419 & Unsig. & Unachieved \\
\hline $\mathrm{CR} \ldots \mathrm{ROE}$ & -.004 & -.039 & .969 & Unsig. & Unachieved \\
\hline $\mathrm{OR} \ldots \mathrm{ROE}$ & .192 & 2.155 & .031 & Sig. & Achieved \\
\hline $\mathrm{MR} \ldots \mathrm{ROE}$ & .119 & 1.334 & .182 & Unsig. & Unachieved \\
\hline $\mathrm{LR} \ldots \mathrm{ROE}$ & .150 & 1.839 & .066 & Unsig. & Unachieved \\
\hline
\end{tabular}

For indirect effects which examine the mediator role of liquidity in the relationship between banking risk and profitability. Figure 4 explains this model of the relationship. The figure shows that all fitness indices were achieved since $\chi^{2}$ was 302.553 , DF was 243 , GFI reached .917 , CFI reached .983, RMSEA reached .030, and p-value was .006 for the model. 


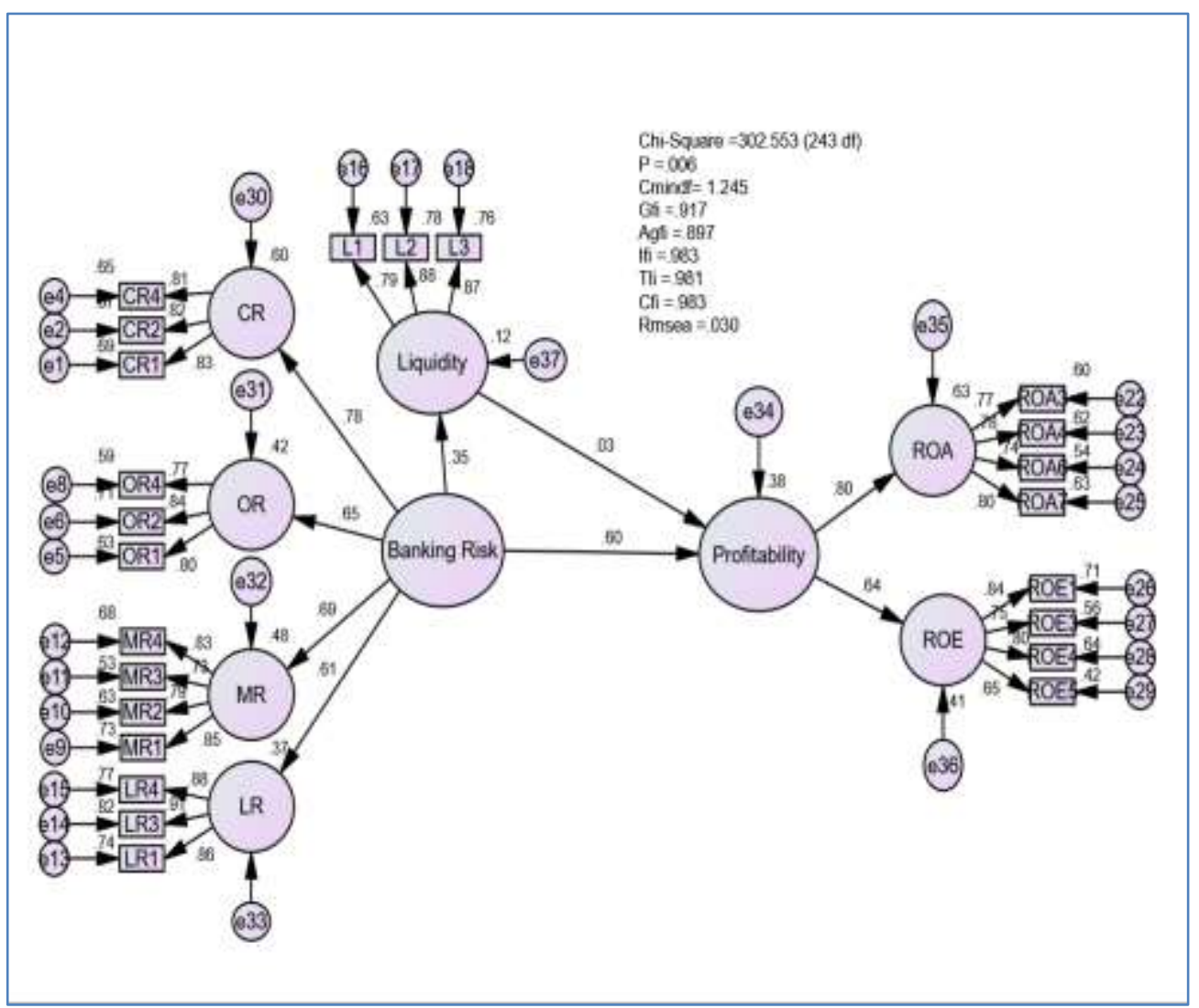

Fig-4: The Standardized Regression Weights for Testing Liquidity as the Mediator in the Relationship

The text output explaining the results in Figure 4 are presented in table 9 . However, the mediator occurs when the indirect effect is greater than direct effect. In addition, type of mediator can be partial mediation or complete mediation. First state occurs when the path from independent variable to mediator variable is significant as well as the path from mediator to dependent variable is significant also [33].

Table 9 referrers that indirect effect < direct effect, and consequently, the bank's liquidity does not work as the mediation in the relationship between banking risk and bank's profitability.

Table-9: Structural Parameters of the Mediation Role of Lq for the Relationship of B.R and Prof

\begin{tabular}{|l|c|c|c|}
\hline \multicolumn{1}{|c|}{ Path } & Direct Effect & Indirect Effect & Result \\
\hline Lq $\rightarrow$ Prof & .03 & - & \multirow{2}{*}{ Unsupported } \\
\hline B.R $\rightarrow$ Prof & .60 & - & \\
\hline B.R $\rightarrow$ Lq $\rightarrow$ Prof & .35 & $(.03 \times .35)=0.01$ & \\
\hline
\end{tabular}

On the other hand, banking risk was tested as mediation in the relationship between liquidity and profitability. Figure 5 explains this model of the relationship. The figure appears that all fitness indices were achieved since $\chi^{2}$ was 302.553 , DF was 243 , GFI reached .917 , CFI reached .983 , RMSEA reached .030 , and p- value was .006 for the model. 


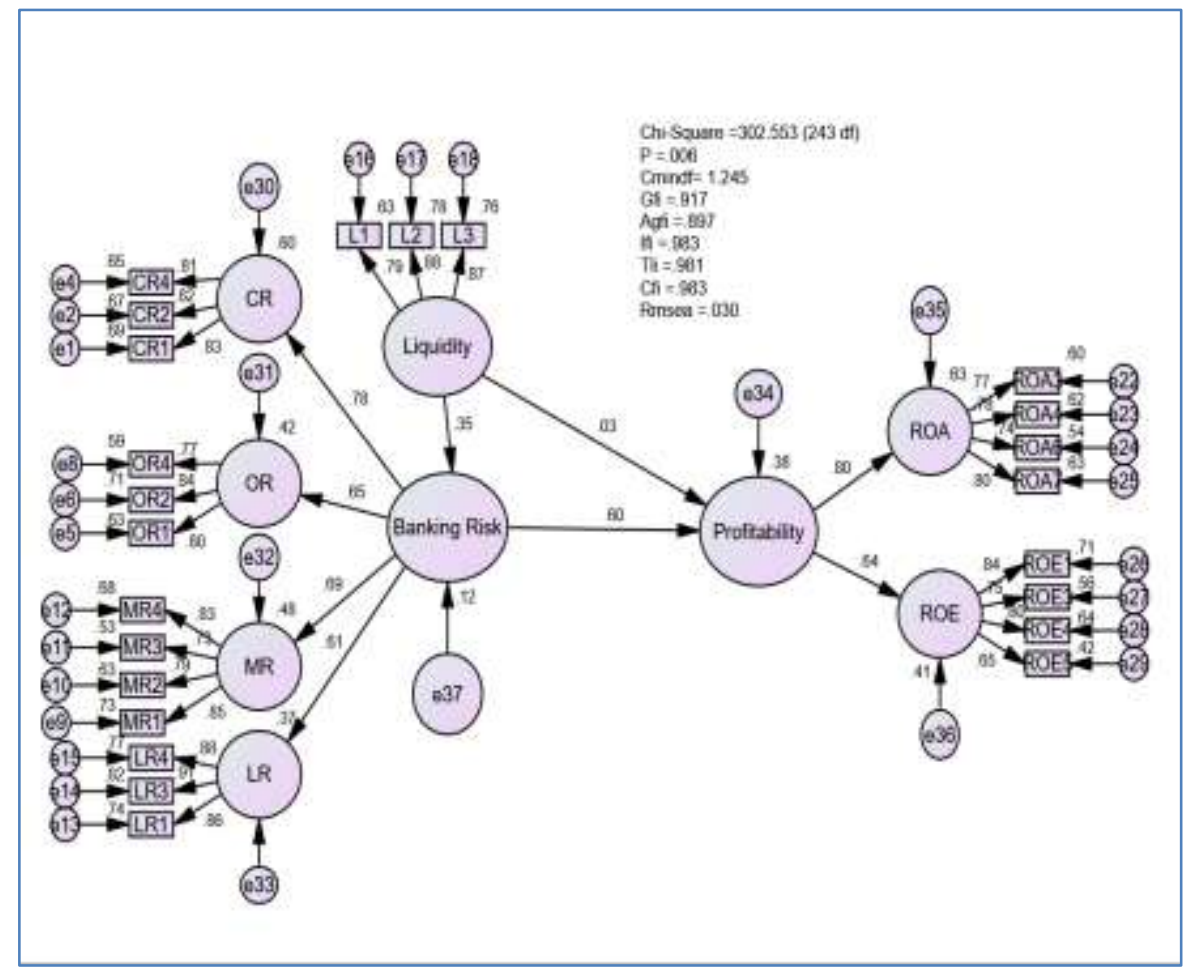

Fig-5: The Standardized Regression Weights for Testing Liquidity as the Mediator in the Relationship

The text output explaining the results in Figure 5 are presented in Table 10. The table indicates that indirect effect (.21) greater than direct effect (.03), and consequently, the banking risk is mediation in the relationship between liquidity and bank's profitability. Given that the relationship between the liquidity and profitability is not significant, so the banking risk is complete mediation.

Table-10: Structural Parameters of the Mediation Role of Lq for the Relationship of B.R and Prof

\begin{tabular}{|l|c|c|c|}
\hline \multicolumn{1}{|c|}{ Path } & Direct Effect & Indirect Effect & Result \\
\hline Lq - Prof & .03 & - & Supported \\
\hline B.R - Prof & .60 & - & \\
\hline B.R - . & .35 & $(.35 \times .60)=.21$ & \\
\hline
\end{tabular}

\section{DISCUSSION AND RECOMMENDATIONS}

The current study differed in its methodology from previous studies such as the $[8,24,15]$.study, as it relied on the questionnaire to collect data. The questionnaire was designed based on theoretical and procedural concepts of the study variables. EFA was used to reduce the items and verify the underlying factors of these variables. CFA was used also to verify the validity of the usage to confirm validity of the metrics used. The results of the EFA and CFA were satisfactory and were according to the recommended levels.

The direct relationships between liquidity, banking risk and profitability have been tested from the perspective of officials of commercial banks in the Libyan West (Table 7). The findings of the multiple regression analysis test indicated that liquidity did not have a statistically significant effect on profitability while banking risk had a positive effect. Comparing the findings of the current study with the findings of previous studies, a difference was observed in those findings. For example, [17-19] works showed that the relationship between liquidity and profitability was positive. Others such as $[16,21]$ revealed that the relationship between liquidity and profitability was negative. In contrast, the results of the study agreed with the results of the study of Lartey, Antwi, and Boadi (2013) (Lartey, Antwi, \& Boadi , 2013)who found that there was a very weak positive relationship between the liquidity and the profitability of the listed banks in Ghana.

The findings of the multiple regression analysis (Table 7) also revealed that the banking risk had positive effect the bank profitability since the level of the impact was middle $(\boldsymbol{\beta}=.386)$. The present study was distinguished from previous studies in that it was able to measure the effect of the overall risk (CR, OR, $\mathrm{MR}$, and LR) on the overall profitability (ROA and $\mathrm{ROE}$ ) of commercial banks.

In addition, the multiple regression analysis findings indicated that two factors affected return on assets and a factor impacted on return on equity. Market risk and liquidity risk weakly impacted on return on 
assets since $\boldsymbol{\beta}$ values were .19 and .17 respectively, while the rest of the factors did not have any significant effect. On the other hand, only on factor is called operational risk had a significant poor effect on return on equity, where the $\boldsymbol{\beta}$ value scored.19 (Table 8).

On the other hand, the study showed good results with regard to median relations. Although liquidity has never directly affected profitability, it indirectly affects it through bank risk, since liquidity and banking risk as predictors of profitability explain .38 of its variance (figure 4). This finding is very important for commercial bank officials. In other words, the relationship between liquidity and profitability could be indirect. This issue supports that most dependent variables are affected by a combination of factors, not just one.

According to discussion above, this study concludes that the results of previous studies that indicated a negative relationship between liquidity and profitability are not always correct due to a simple reason since sometimes the bank profitability may increase or decrease with good or bad reputation for it, or high customer satisfaction and confidence towards the bank. In conclusion, this study recommends studying intermediate relationships, especially with confidence, loyalty, contentment and reputation.

\section{REFFERENCE}

1. Abbas F, Iqbal S, Aziz B. The impact of bank capital, bank liquidity and credit risk on profitability in postcrisis period: A comparative study of US and Asia. Cogent Economics \& Finance. 2019 Jan 1;7(1):1605683.

2. Adebayo O, David AO, Samuel OO. Liquidity management and commercial banks' profitability in Nigeria. Research Journal of Finance and Accounting. 2011;2(7/8):24-38.

3. Rifqah Amaliah S, Hassan HH. The Relationship between Bank's Credit Risk, Liquidity, and Capital Adequacy towards its Profitability in Indonesia.

4. Bassey FA, Tobi EG, Bassey IF, Ekwere RE. Liquidity management and the performance of banks in Nigeria. International journal of academic research in accounting, finance and management sciences. 2016;6(1):41-8.

5. Tulsian M. Profitability Analysis (A comparative study of SAIL \& TATA Steel). Journal of Economics and Finance. 2014;3(2):19-22.

6. Elsharif TA. The Impact of Liquidity Management on Profitability. 2016; Retrieved May 24, 2020, from Research Gate: www.researchgate.net/publication.

7. Noman AH, Pervin S, Chowdhury MM, Banna H. The effect of credit risk on the banking profitability: A case on Bangladesh. Global journal of management and business research. $2015 \mathrm{Apr}$ 22.
8. Alshatti AS. The effect of the liquidity management on profitability in the Jordanian commercial banks. International Journa

9. Oberoi M Bank Risks: Everything You Need to Know. 2019. Retrieved May 2, 2020, from Market Realist: https://marketrealist.com.

10. Kolapo TF, Ayeni RK, Oke MO. Credit risk and commercial banks'performance in nigeria: a panel model approach. Australian journal of business and management research. 2012 May 1;2(2):31.

11. Shaw $\mathrm{S}$. What are various types of risks a bank faces?. 2016. Retrieved April 17, 2020, from Quora: www.quora.com.

12. Shaw $\mathrm{S}$. What is the relationship between profit and risk?.2016. Retrieved May 21, 2020, from Quora: www.quora.com.

13. Maaka ZA. The relationship between liquidity risk and financial performance of commercial banks in Kenya (Doctoral dissertation, University of Nairobi).

14. Kashyap AK, Rajan R, Stein JC. Banks as liquidity providers: An explanation for the coexistence of lending and deposit- taking. The Journal of finance. $2002 \mathrm{Feb} ; 57(1): 33-73$.

15. Olalekan A, Adeyinka S. Capital adequacy and banks' profitability: an empirical evidence from Nigeria. American International Journal of Contemporary Research. 2013 Oct;3(10):87-93.

16. Goddard J, Molyneux P, Wilson JO. Dynamics of growth and profitability in banking. Journal of money, credit and banking. 2004 Dec 1:1069-90.

17. Bourke P. Concentration and other determinants of bank profitability in Europe, North America and Australia. Journal of Banking \& Finance. 1989 Mar 1;13(1):65-79.

18. Eichengreen B and Gibson HD. Greek Banking at the Dawn of the New Millennium; 2001.

19. Bordeleau É, Graham C. The impact of liquidity on bank profitability. Bank of Canada; 2010 Dec 23.

20. Islam MS, Nishiyama SI. The determinants of bank profitability: dynamic panel evidence from South Asian countries. Journal of Applied Finance and Banking. 2016 May 1;6(3):77.

21. Molyneux P, Thornton J. Determinants of European bank profitability: A note. Journal of banking \& Finance. 1992 Dec 1;16(6):1173-8.

22. Tran VT, Lin CT, Nguyen H. Liquidity creation, regulatory capital, and bank profitability. International Review of Financial Analysis. 2016 Dec 1;48:98-109.

23. Saleem Q, Rehman RU. Impacts of liquidity ratios on profitability. Interdisciplinary journal of research in business. $2011 \mathrm{Jul}$;1(7):95-8.

24. Berríos MR. The relationship between bank credit risk and profitability and liquidity. The International Journal of Business and Finance Research. 2013;7(3):105-18.

25. Salah NB, Fedhila H. Effects of securitization on credit risk and banking stability: Empirical evidence from American commercial banks. 
International Journal of Economics and Finance. 2012 May;4(5):194-207.

26. Shair F, Sun N, Shaorong S, Atta F, Hussain M. Impacts of risk and competition on the profitability of banks: Empirical evidence from Pakistan. PloS one. 2019 Nov 11;14(11):e0224378.

27. Kayode OF, Obamuyi TM, Owoputi JA, Adeyefa FA. Credit risk and bank performance in Nigeria. IOSR Journal of Economics and Finance. 2015;6(2):21-8.

28. Ruziqa A. The impact of credit and liquidity risk on bank financial performance: the case of Indonesian Conventional Bank with total asset above 10 trillion Rupiah. International Journal of Economic Policy in Emerging Economies. 2013 Jan 1;6(2):93-106.

29. Walumbwa FO, Hartnell CA. Understanding transformational leadership-employee performance links: The role of relational identification and selfefficacy. Journal of occupational and organizational psychology. 2011 Mar;84(1):15372.
30. Kaiser HF. An index of factorial simplicity. Psychometrika.1974; 39: 31-36.

31. Vansickle T. Test Reliability Indicates More than Just Consistency. Assessment Brief. April. 2015 Apr.

32. Drost EA. Validity and reliability in social science research. Education Research and perspectives. 2011;38(1):105.

33. Awang Z. SEM Made Simple: A Gintle Approach to Learning Structure Equation Modeling. Bandar Baru Bangi, Selangor: MPWS Rich Publication Sdn.2015.

34. Hair JJ, Black WC, Babin BJ and Anderson RE. Multivariate Data Analysis: A Global Perspective. (ed), Ed.) Englewood Cliffs, NJ: Pearson Prentice Hall Upper Saddle River, NJ.2010.

35. Lartey VC, Antwi S and Boadi EK. The Relationship between Liquidity and Profitability of Listed Banks in Ghana. International Journal of Business and Social Science. 2013; 4(3), 48-56. 